\title{
Male-specific Fruitless isoforms have different regulatory roles conferred by distinct zinc finger DNA binding domains
}

\author{
Justin E Dalton ${ }^{1 \dagger}$, Justin M Fear ${ }^{2,3,4 \dagger}$, Simon Knott $^{5}$, Bruce S Baker ${ }^{6}$, Lauren M Mclntyre ${ }^{3,4}$ \\ and Michelle N Arbeitman ${ }^{1,7^{*}}$
}

\begin{abstract}
Background: Drosophila melanogaster adult males perform an elaborate courtship ritual to entice females to mate. fruitless (fru), a gene that is one of the key regulators of male courtship behavior, encodes multiple male-specific isoforms $\left(F^{M}{ }^{M}\right)$. These isoforms vary in their carboxy-terminal zinc finger domains, which are predicted to facilitate DNA binding.

Results: By over-expressing individual Fru ${ }^{\mathrm{M}}$ isoforms in fru-expressing neurons in either males or females and assaying the global transcriptional response by RNA-sequencing, we show that three Fru ${ }^{\mathrm{M}}$ isoforms have different regulatory activities that depend on the sex of the fly. We identified several sets of genes regulated downstream of $\mathrm{Fru}^{\mathrm{M}}$ isoforms, including many annotated with neuronal functions. By determining the binding sites of individual $\mathrm{Fru}^{\mathrm{M}}$ isoforms using SELEX we demonstrate that the distinct zinc finger domain of each Fru ${ }^{\mathrm{M}}$ isoforms confers different DNA binding specificities. A genome-wide search for these binding site sequences finds that the gene sets identified as induced by over-expression of $\mathrm{Fru}^{\mathrm{M}}$ isoforms in males are enriched for genes that contain the binding sites. An analysis of the chromosomal distribution of genes downstream of $\mathrm{Fru}^{\mathrm{M}}$ shows that those that are induced and repressed in males are highly enriched and depleted on the X chromosome, respectively.

Conclusions: This study elucidates the different regulatory and DNA binding activities of three $\mathrm{Fru}^{\mathrm{M}}$ isoforms on a genome-wide scale and identifies genes regulated by these isoforms. These results add to our understanding of sex chromosome biology and further support the hypothesis that in some cell-types genes with male-biased expression are enriched on the $\mathrm{X}$ chromosome.
\end{abstract}

Keywords: Fruitless, Sex hierarchy, Drosophila, Behavior, Genomics, RNA-seq

\section{Background}

In Drosophila melanogaster differences in adult reproductive behaviors are specified by the somatic sex determination hierarchy (hereafter called sex hierarchy), a multi-branched hierarchy with functions in directing both sexual development and dosage compensation (Figure 1) reviewed in $[1,2]$. The branch of the sex hierarchy critical for specifying adult behaviors consists of

\footnotetext{
* Correspondence: michelle.arbeitman@med.fsu.edu

${ }^{\dagger}$ Equal contributors

'Biomedical Sciences Department and Program in Neuroscience, Florida State University, College of Medicine, Tallahassee, FL 32303, USA

${ }^{7}$ Department of Biomedical Sciences, Florida State University, 1115 West Call Street, Tallahassee, FL 32306, USA

Full list of author information is available at the end of the article
}

a pre-mRNA splicing cascade that regulates the sexspecific splicing of transcripts from doublesex $(d s x)$ and fruitless (fru) (Figure 1) reviewed in [3,4]. fru was initially shown to be important for male courtship behavior based on the phenotypes of mutant males that displayed high levels of male-male courtship behaviors [5]. This was distinct from the phenotypic observations with respect to other mutants that impacted courtship behaviors, in that the phenotype of the fru mutant was specific to courtship behaviors. Later, molecular-genetic analyses of fru demonstrated the position of fru in the sex hierarchy, and showed that it was required for all aspects of male courtship behaviors, providing strong evidence that fru is a key regulator of male courtship behavior [6-10].

\section{Biomed Central}




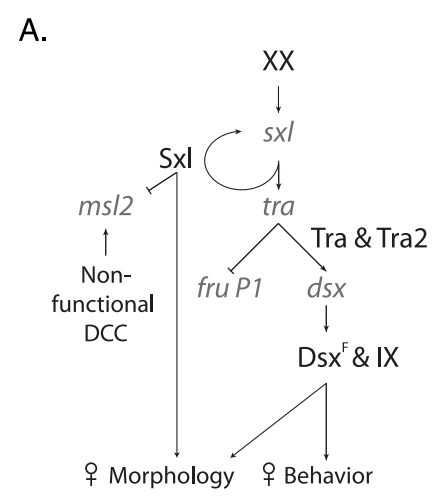

C.

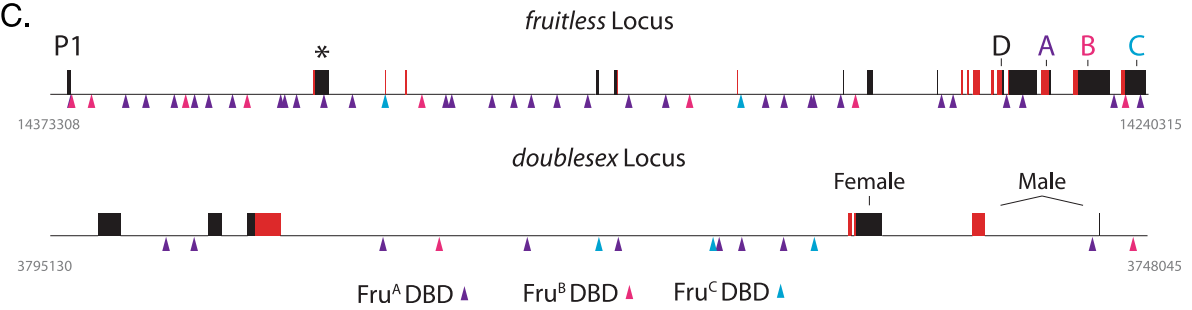

Figure 1 Fruitless, a gene in the sex-determination hierarchy, encodes multiple male-specific isoforms with distinct zinc finger domains. (A) The Drosophila somatic sex determination hierarchy has two branches--one regulates dosage compensation and the other somatic sexual development. In females (chromosomally XX) Sxl is produced and so dosage compensation is not active. In males there is no Sxl and dosage compensation is active, resulting in increased expression of the single male X chromosome. For somatic sexual development, Sxl regulates the splicing of its own pre-mRNA and the transformer (tra). The product of tra (Tra) along with Transformer-2 (Tra2), coordinate to regulate splicing of transcripts produced from doublesex (dsx) and the P1 promoter of fruitless (fru P1). This branch of the hierarchy culminates in the production of sex-specific transcription factors (Dsx', Dsx ${ }^{\mathrm{M}}$, and Fru ${ }^{\mathrm{M}}$ ) that specify sex-specific morphology and behaviors. Grey indicates transcripts; black indicates proteins. (B) Schematic of FruM proteins. Male-specific 101 amino acid region (Black), a bric-a-brac, tramtrack, broad-complex domain (BTB), and distinct zinc finger domains ( $\mathrm{A}, \mathrm{B}$, or $\mathrm{C}$ ) are indicated. (C) fruitless and doublesex locus. Coding exons (red bars), non-coding exons (black bars), sex-specifically spliced exon of fru (asterisks), first fru promoter (P1), exons encoding the zinc-finger DNA binding domains (A-D), and male- and female-specific exons for dsx are indicated. The DNA binding motifs (triangles) for A (purple), B (pink) or C (cyan) DNA binding domains of Fru ${ }^{M}$ are indicated.

fru is a complex locus that encodes both sex-specific and non-sex-specific proteins through the production of transcripts from at least four different promoters $(P 1-4)$ [6,7]. Transcripts expressed from the fru $P 1$ promoter are critical for male courtship behaviors, and are the only fru pre-mRNAs that are spliced by the sex hierarchy (Figure 1). fru $P 1$ transcripts produce multiple male-specific isoforms $\left(\mathrm{Fru}^{\mathrm{M}}\right)$ in $\sim 2-5 \%$ of all central nervous system (CNS) neurons and these neurons have been shown to be important for courtship behaviors [11-14]. fru P1 expressing neurons are present in both males and females $[6,11,13,14]$, but the $\mathrm{Fru}^{\mathrm{M}}$ protein isoforms are produced only in males where they contribute to building the potential for male courtship into the nervous system during development [15-18]. Conversely, fru P1 transcripts in females are not translated $[19,20]$. All Fru isoforms are members of a family of conserved proteins that contain a BTB (BTB for bric-a-brac, tramtrack, broad-complex) domain and a zinc finger domain (Figure 1). $\mathrm{Fru}^{\mathrm{M}}$ isoforms contain an aminoterminal 101 amino acid region of unknown function that is not present in Fru isoforms common to both sexes. fru P1 transcripts are alternatively spliced at their
3' ends into one of five exons that encode different zinc finger domains, which are predicted DNA binding domains (DBD; named A-E) $[6,19,21,22]$. Thus, fru is predicted to encode transcription factors. However, there is no direct evidence of $\mathrm{Fru}^{\mathrm{M}}$ transcriptional activities, other than association with known chromatin modifying proteins [20].

Three of the five predicted $\mathrm{Fru}^{\mathrm{M}}$ isoforms have been shown to be the predominate isoforms in adult head and central nervous system tissues ( $\mathrm{Fru}^{\mathrm{MA}}$, Fru ${ }^{\mathrm{MB}}$ and $\mathrm{Fru}^{\mathrm{MC}}$ ) [22]. These isoforms display differences in their expression patterns and in their ability to rescue male courtship defects [22]. As a first step to mechanistically understanding how $\mathrm{Fru}^{\mathrm{M}}$ isoforms specify the potential for male courtship behaviors, the DNA binding specificities of each $\mathrm{Fru}^{\mathrm{M}}$ isoform needs to be determined and the sets of genes that are regulated downstream of each $\mathrm{Fru}^{\mathrm{M}}$ isoform identified. The identification of genes regulated by each $\mathrm{Fru}^{\mathrm{M}}$ isoform will also contribute to our understanding of how fru functions to establish the potential for sex-specific behaviors.

Here, we identify genes that are induced or repressed by $\mathrm{Fru}^{\mathrm{M}}$ by examining gene expression in adult head tissues where we over-express individual $\mathrm{Fru}^{\mathrm{M}}$ isoforms 
$\left(\mathrm{Fru}^{\mathrm{MA}}, \mathrm{Fru}^{\mathrm{MB}}\right.$ and $\left.\mathrm{Fru}^{\mathrm{MC}}\right)$ in $f r u P 1$-expressing neurons of either males or females. We show that each isoform has different regulatory activities and that the sex of the fly impacts which genes change expression as a consequence of $\mathrm{Fru}^{\mathrm{M}}$ over-expression. Similar over-expression conditions were previously used to demonstrate that $\mathrm{Fru}^{\mathrm{M}}$ is sufficient, when expressed in female fru P1-expressing neurons, to specify the potential for nearly all aspects of male courtship behavior $[4,12,14]$. We used an in vitro binding site selection technique (SELEX) to identify the sequence motifs bound by each of three $\mathrm{Fru}^{\mathrm{M}}$ isoforms and show that each isoform has different binding specificity [reviewed in 23,24]. For each gene, the coding sequence and the regulatory region (defined as $2 \mathrm{~kb}$ upstream and $2 \mathrm{~kb}$ downstream of the coding sequence) was examined for the presence of these binding sites. Genes containing these binding sites are enriched in the gene sets induced by over-expression of the respective $\mathrm{Fru}^{\mathrm{M}}$ isoform in males, and in the genes identified as induced by $\mathrm{Fru}^{\mathrm{M}}$ in loss-of-function mutant analyses. Additionally, genes induced by $\mathrm{Fru}^{\mathrm{M}}$, are enriched on the $\mathrm{X}$ chromosome, whereas those that are repressed by $\mathrm{Fru}^{\mathrm{M}}$ are under represented on the $\mathrm{X}$ chromosome.

\section{Results}

The goal of our study was to identify genes whose expression was modulated (either up or down) by fru P1 in the nervous system. To this end, we carried out a set of parallel experiments in which the GAL4/UAS system was used to overexpress each of the three best-characterized $\mathrm{Fru}^{\mathrm{M}}$ isoforms (Fru ${ }^{\mathrm{MA}}$, $\mathrm{Fru}^{\mathrm{MB}}$ and $\mathrm{Fru}^{\mathrm{MC}}$; Figure 1) $[6,7,22]$, in just the fru P1-expressing neurons [14]. RNA-sequencing (RNA-seq) analysis was performed on mRNA extracted from the heads of such flies to identify differential expression on a genome-wide level, with exon-level resolution. We compared expression in heads in either male or female flies over-expressing one of the $\mathrm{Fru}^{\mathrm{M}}$ isoforms, as compared to wild type adult male or female heads, respectively. This allows us to determine if there are differences in individual $\mathrm{Fru}^{\mathrm{M}}$ isoform activities and if there are sex-specific factors that function in conjunction with $\mathrm{Fru}^{\mathrm{M}}$. In addition, we examined gene expression differences in males mutant for fru P1 (two different allele combinations; see Materials and Methods) compared to wild type males.

One of the strengths of RNA-seq analysis is the ability to detect differences in isoform expression levels. This is because exons are used for estimating expression, and thus the presence and difference in amount of transcript from alternative exon cassettes can be used directly to make inferences about isoforms. We focused on exon level expression and used existing models of transcript isoforms to identify alternative exon structures. Next, we tested for differential expression in our comparisons for each exon separately [see Materials and Methods and 25], and then used existing gene models to make inferences about differential expression of isoforms.

\section{$\mathrm{Fru}^{\mathrm{M}}$ isoforms have different activities}

To determine if $\mathrm{Fru}^{\mathrm{MA}}$, $\mathrm{Fru}^{\mathrm{MB}}$ and $\mathrm{Fru}^{\mathrm{MC}}$ had different effects on gene expression in fru P1-expressing neurons we determined the gene sets that have exons that are both (1) statistically significantly induced or repressed and (2) have a $\geq 2$ fold change in expression level when the data from animals overexpressing each $\mathrm{Fru}^{\mathrm{M}}$ isoform are compared separately to the data from both CS and Berlin males (Additional file 1: Table S1). We found that over-expression of each $\mathrm{Fru}^{\mathrm{M}}$ isoform leads to different subsets of genes with exons whose transcription is either induced or repressed. As expected, when we over-express each $\mathrm{Fru}^{\mathrm{M}}$ isoform we found that the exon encoding the respective Fru DBD is significantly up regulated.

Over-expression of $\mathrm{Fru}^{\mathrm{MA}}$, Fru ${ }^{\mathrm{MB}}$ and $\mathrm{Fru}^{\mathrm{MC}}$ leads to 752, 739 and 927 genes with higher expression than wild type males, respectively. There were 460 genes with higher expression in all three conditions (Figure 2A and Additional file 1: Table S1; Additional file 2: Figure S1; $\mathrm{Fru}^{\mathrm{M}}$-induced genes). We found that substantially more genes are up-regulated, than down regulated, relative to wild type expression. Over-expression of $\mathrm{Fru}^{\mathrm{MA}}$, $\mathrm{Fru}^{\mathrm{MB}}$ and $\mathrm{Fru}^{\mathrm{MC}}$ lead to 204, 259 and 295 genes with lower expression than in wild type males, respectively. There are 55 genes with lower expression in all three conditions (Figure 2B and Additional file 1: Table S1; $\mathrm{Fru}^{\mathrm{M}}$-repressed genes).

\section{$\mathrm{Fru}^{\mathrm{M}}$ isoforms have different activities in males as compared to females}

Using the same criteria as above, we examined the numbers of genes differentially expressed when $\mathrm{Fru}^{\mathrm{M}}$ isoforms are over-expressed in female fru P1-expressing neurons as compared to wild type females of CS and Berlin strains. The rationale for these comparisons was to determine if there are additional sex-specific differences in fru P1expressing neurons that might influence $\mathrm{Fru}^{\mathrm{M}}$ activities. Over-expression of $\mathrm{Fru}^{\mathrm{MA}}$, Fru ${ }^{\mathrm{MB}}$ and $\mathrm{Fru}^{\mathrm{MC}}$ in females leads to 111, 117 and 167 genes with higher expression than wild type females, respectively. There are 42 genes having higher expression in all three conditions, which included the exon encoding the respective Fru DBD (Figure 2C; Additional file 2: Figure S1 and Additional file 3: Table S2). Over-expression of $\mathrm{Fru}^{\mathrm{MA}}$, $\mathrm{Fru}^{\mathrm{MB}}$ or $\mathrm{Fru}^{\mathrm{MC}}$ lead to 183, 237 and 198 genes with lower expression than wild type females, respectively. There are 42 genes with lower expression in all three conditions (Figure 2D).

These results further demonstrate that each $\mathrm{Fru}^{\mathrm{M}}$ isoform has different activities with respect to regulating gene expression. In female fru P1-expressing neurons, 
A.

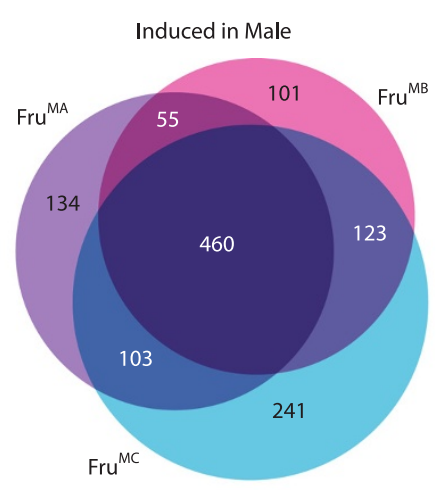

C.

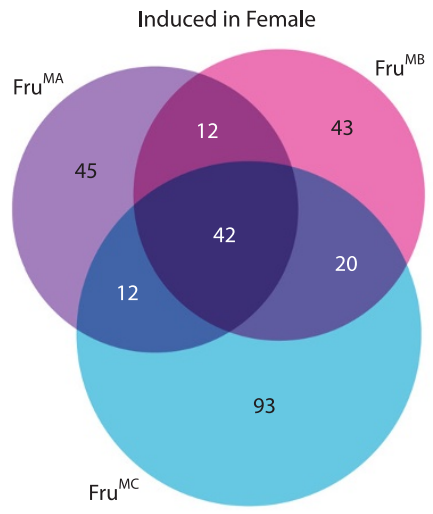

E.

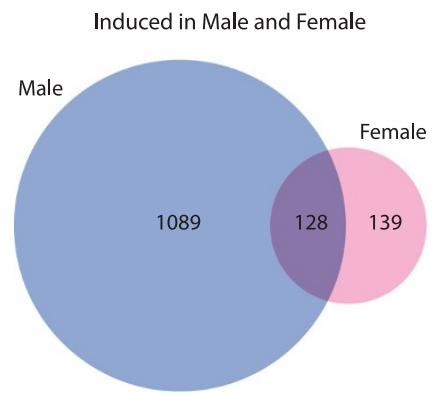

B.

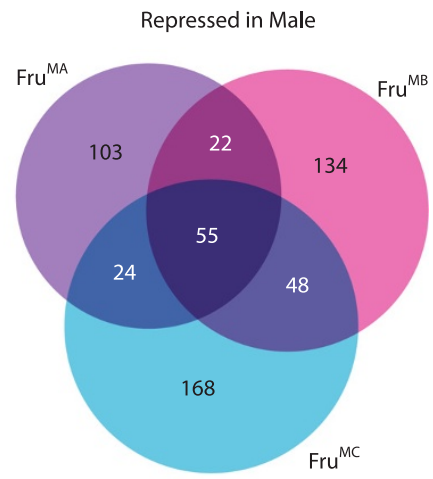

D.

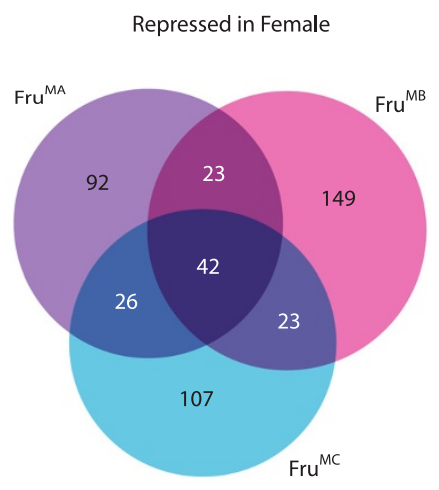

F.

Repressed in Male and Female

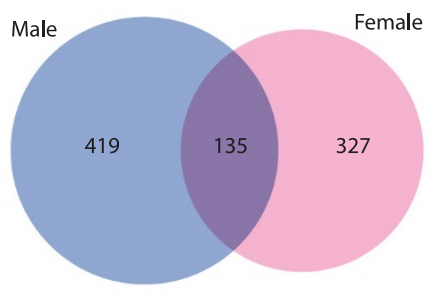

Figure $2 \mathrm{Fru}^{\mathrm{M}}$ isoforms have both distinct and overlapping sets of regulated genes. (A-F) Venn diagrams displaying number of distinct and mutual genes between different sets of differentially expressed genes. (A-D) Numbers of genes induced or repressed in males or females by over-expression of $\mathrm{Fru}^{\mathrm{MA}}$, Fru ${ }^{\mathrm{MB}}$ or $\mathrm{Fru}^{\mathrm{MC}}$ in fru P1-expressing neurons of the head. (E-F) Numbers of all genes induced or repressed by over-expression of any of the $\mathrm{Fru}^{\mathrm{M}}$ isoforms.

more genes are repressed rather than induced when each isoform is expressed. This is in contrast to our observations in males. Taken together these findings suggest that the activity of each $\mathrm{Fru}^{\mathrm{M}}$ isoform is influenced by the sex in which it is produced. This suggests that there may be other factors that are present in a sex-specific manner in fru P1-expressing neurons to influence $\mathrm{Fru}^{\mathrm{M}}$ isoform activities.

Next, we determined if there are differences in the sets of genes that are induced or repressed by the overexpression of $\mathrm{Fru}^{\mathrm{M}}$ isoforms in males and females. We determined the union of the genes that are induced by any of the three $\mathrm{Fru}^{\mathrm{M}}$ isoforms in either males or females (Figure 2E and F). There are 1217 genes and 267 genes induced by any of the three $\mathrm{Fru}^{\mathrm{M}}$ isoforms in males and females, respectively. The intersection of the induced genes in males and females is 128 genes (Figure 2E). We also determined the union of the genes that are repressed by any of the three $\mathrm{Fru}^{\mathrm{M}}$ isoforms in either males or females. There are 554 genes and 462 genes repressed by one of the three $\mathrm{Fru}^{\mathrm{M}}$ isoforms in males and females, respectively. The intersection of the repressed genes in 
males and females is 135 genes (Figure 2F). The genes induced in both males and females include $d s x$, Gustatory receptor $93 a$, serotonin receptor $1 A$, semaphorin-5c (Additional file 1: Table S1 and Additional file 3: Table S2). The genes repressed in males and females include genderblind, methuselah-like 8 (Additional file 1: Table S1 and Additional file 3: Table S2). These genes are those for which over-expression of $\mathrm{Fru}^{\mathrm{M}}$ isoforms in fru P1-expressing cells can influence gene expression independent of the sex of the fly.

Overall, many more genes are induced by overexpression of each $\mathrm{Fru}^{\mathrm{M}}$ isoform in males as compared to females (Additional file 2: Figure S1), whereas there is not as large a difference in numbers of genes that are repressed by each isoform in males and females, suggesting that there is a sex-specific factor(s) that functions with $\mathrm{Fru}^{\mathrm{M}}$ in males to facilitate gene induction.

\section{Fru isoforms have different DNA binding specificity}

Our results demonstrate that $\mathrm{Fru}^{\mathrm{M}}$ isoforms have different activities with respect to the gene sets that are induced or repressed in response to their expression. One possibility is that this is through differential DNA binding properties of the three isoforms. To address this question, we determined the binding site sequence for $\mathrm{Fru}^{\mathrm{A}}, \mathrm{Fru}^{\mathrm{B}}$ and $\mathrm{Fru}^{\mathrm{C}}$ DBDs using an in vitro selection technique called SELEX (see Materials and Methods). From this analysis, we found that each of the DBDs examined bind different sequence motifs. The consensus motifs identified for the DBDs in the $\mathrm{Fru}^{\mathrm{A}}$, $\mathrm{Fru}^{\mathrm{B}}$ and $\mathrm{Fru}^{\mathrm{C}}$ proteins are AGTAAC, GCCCTTT, and TGTTACATCA, respectively (Figure 3A).

Gel shift analysis, using purified GST-Fru DBD fusion proteins and the identified binding sites for $\mathrm{Fru}^{\mathrm{A}}$ and $\mathrm{Fru}^{\mathrm{C}}$, demonstrate that they each bind specifically to the sequence identified in the SELEX experiment, but do not bind to an oligonucleotide (oligo) containing a randomized sequence with the same nucleotide content (Figure 3B). Furthermore, $\mathrm{Fru}^{\mathrm{A}}$ and $\mathrm{Fru}^{\mathrm{C}}$ did not bind the oligos containing the motifs identified for $\mathrm{Fru}^{\mathrm{C}}$ and $\mathrm{Fru}^{\mathrm{A}}$, respectively (Figure $3 \mathrm{~B}$ ).

When gel shifts were performed using the DBD in the $\mathrm{Fru}^{\mathrm{B}}$ protein, high levels of binding to DNA sequences that are present in each oligo used in these assays, flanking the SELEX identified motif, were observed in the gel shift assay (see Materials and Methods). This could be because the $\mathrm{Fru}^{\mathrm{B}}$ protein has a polyglutamine tract, which is not observed in the other binding domains and this facilitates non-specific association with DNA in the gel shift assay. To ensure that the correct sequence motif was identified for $\mathrm{Fru}^{\mathrm{B}}$, the full SELEX technique was performed two independent times and identified nearly the same consensus sequence.
Fru DNA binding site motifs are significantly enriched in genes that are induced by $\mathrm{Fru}^{\mathrm{M}}$ isoforms

Next, we determined the frequency of each Fru binding site motif on a genome-wide level, in annotated gene regions, including introns and regions $2 \mathrm{~kb}$ upstream and downstream from each gene's annotated start and stop site. We found that genes containing at least one sequence motif for Fru ${ }^{\mathrm{A}}$ DBD are significantly enriched in the sets of genes that are induced downstream of $\mathrm{Fru}^{\mathrm{MA}}$, and similar enrichments were observed for $\mathrm{Fru}^{\mathrm{B}}$ and $\mathrm{Fru}^{\mathrm{C}}$ in males, respectively (Table 1 and Additional file 4: Table S3). We do not see a similar enrichment when we examine the genes repressed downstream $\mathrm{Fru}^{\mathrm{A}}, \mathrm{Fru}^{\mathrm{B}}$ and $\mathrm{Fru}^{\mathrm{C}}$ in males. A very different pattern is observed for genes induced downstream of $\mathrm{Fru}^{\mathrm{A}}$, $\mathrm{Fru}^{\mathrm{B}}$ and $\mathrm{Fru}^{\mathrm{C}}$ in females, with only the gene sets induced downstream $\mathrm{Fru}^{\mathrm{A}}$ showing enrichment of genes containing at least one $\mathrm{Fru}^{\mathrm{A}}$ binding site (Table 1). These results suggest that the sets of genes that are induced in males by $\mathrm{Fru}^{\mathrm{M}}$ over-expression includes genes that may be direct targets of $\mathrm{Fru}^{\mathrm{M}}$, whereas those that are induced in females, or repressed in either males or females by $\mathrm{Fru}^{\mathrm{M}}$ over-expression are not as likely to be direct targets.

$\mathrm{Fru}^{\mathrm{A}}, \mathrm{Fru}^{\mathrm{B}}$ and $\mathrm{Fru}^{\mathrm{C}}$ sites are found in overlapping sets of genes and the presence of a motif for one significantly increases the likelihood of finding a binding site for at least one of the other. This result may explain why there were several genes that were induced by each of the three Fru isoforms in both males and females (see above).

fru has many binding sites with 32, 8 and 2 binding sites motifs for each $\mathrm{Fru}^{\mathrm{A}}$, Fru ${ }^{\mathrm{B}}$ and $\mathrm{Fru}^{\mathrm{C}} \mathrm{DBD}$, respectively (Figure $1 \mathrm{C}$ ). Additionally, $d s x$ has a large number of binding sites with 9, 2 and 3 binding sites motifs for $\mathrm{Fru}^{\mathrm{A}}$, Fru ${ }^{\mathrm{B}}$ and $\mathrm{Fru}^{\mathrm{C}} \mathrm{DBD}$, respectively (Figure $1 \mathrm{C}$ ), although it should be noted that both fru and $d s x$ are large genes. $\mathrm{Fru}^{\mathrm{M}}$ may regulate $d s x$ expression directly, consistent with the overlap observed between Dsx and $\mathrm{Fru}^{\mathrm{M}}$ in the CNS [26,27], it may also regulate its own expression. This regulation of both $d s x$ and fru transcript levels by $\mathrm{Fru}^{\mathrm{M}}$ isoforms could ensure sufficient $d s x$ and fru expression in neurons important for male courtship behaviors.

\section{Genes with roles in neuronal patterning and physiology are enriched among genes regulated by Fru $^{\mathrm{M}}$ isoforms in males and not in females}

fru P1-expressing neurons are present in very similar positions and numbers in adult males and females. To gain insight into the processes $\mathrm{Fru}^{\mathrm{M}}$ regulates, we examined gene ontology (GO) enrichment of protein domains [28] and biological processes, molecular functions and cellular processes [29] for $\mathrm{Fru}^{\mathrm{M}}$ regulated genes (Additional file 5: Table S4). For the 1,217 genes up-regulated by 
A.

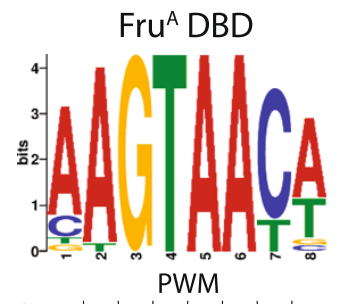

A $75|95| 0|0| 100|100| 0 \mid 60$

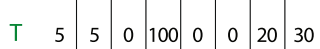

\begin{tabular}{ll|l|l|l|l|l|l|l} 
C 15 & 0 & 0 & 0 & 0 & 0 & 80 & 5
\end{tabular}

\begin{tabular}{ll|l|l|l|l|l|l|l} 
G & 5 & 0 & 100 & 0 & 0 & 0 & 0 & 5
\end{tabular}

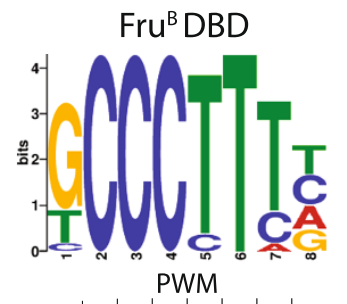

A $\quad 0 \quad 0|0|$\begin{tabular}{ll|l|l|l|l} 
& 0 & 0 & 5 & 10 & 25
\end{tabular}

\begin{tabular}{ll|lllllllll} 
T & 25 & 0 & 0 & 5 & 85 & 90 & 65 & 25
\end{tabular}

\begin{tabular}{ll|l|l|l|l|l|l|l} 
C $\quad 5$ & 100 & 95 & 95 & 15 & 0 & 25 & 25
\end{tabular}

\begin{tabular}{ll|l|l|l|l|l|l} 
G 70 & 0 & 5 & 0 & 0 & 5 & 0 & 25
\end{tabular}

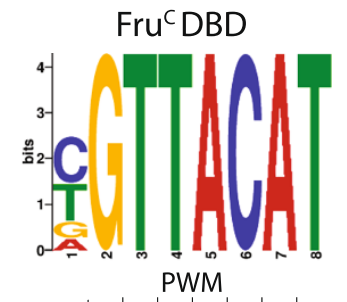

A $11|0| 0|0| 0|100| 0|100| 0$

\begin{tabular}{cc|c|c|c|c|c|c|c} 
T & 33 & 0 & 100100 & 0 & 0 & 0 & 100
\end{tabular}

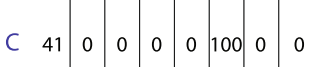

G $15|100| 0 \mid \begin{array}{lllllll} & 0 & 0 & 0 & 0\end{array}$

B.

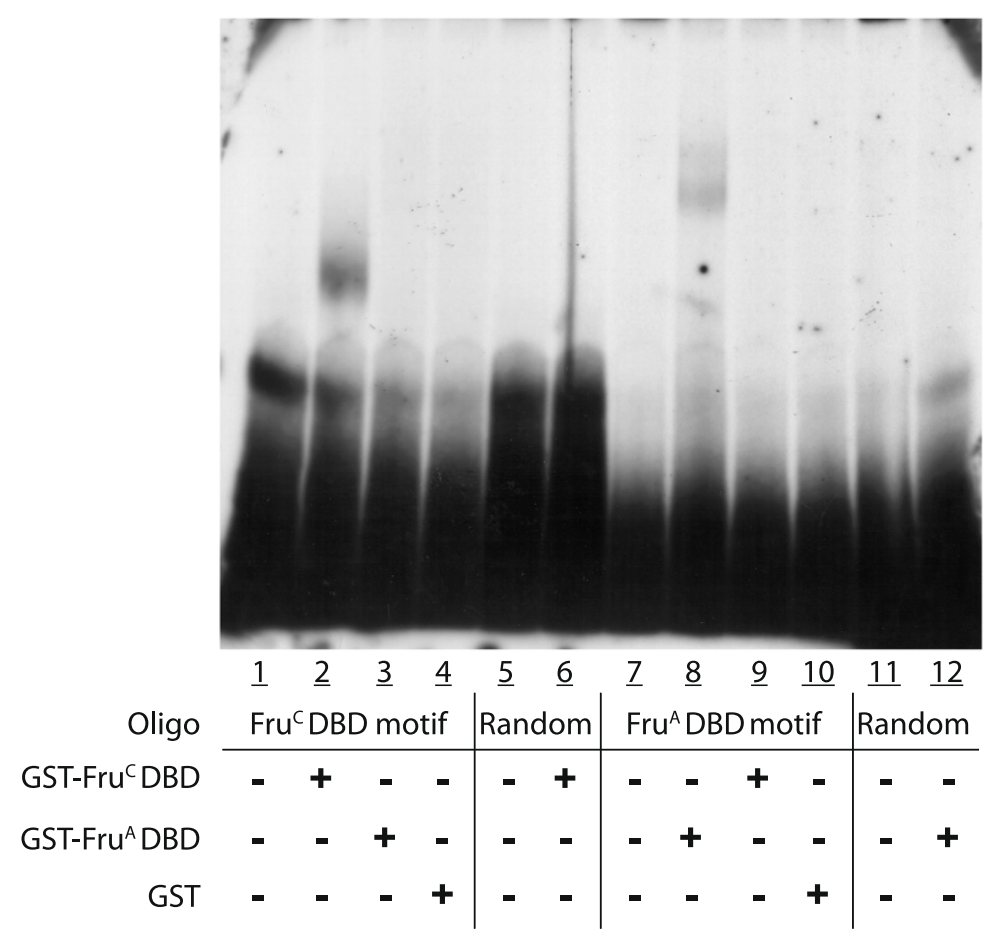

Figure 3 Identification of DNA binding motifs for the A, B and C zinc finger domains of Fru ${ }^{\mathrm{M}}$. (A) Consensus DNA binding sequences of the zinc finger DNA binding domains (DBD) of Fru ${ }^{\mathrm{MA}}$, Fru ${ }^{\mathrm{MB}}$ or $\mathrm{Fru}^{\mathrm{MC}}$ identified after ten rounds of SELEX. (B) Oligonucleotides containing the consensus sequences identified by SELEX, or sequences of the same nucleotide content but randomized in order, for DBD ${ }^{A}$ or $D B D^{C}$ were incubated with GST-FruA DBD or GST-Fru ${ }^{\mathrm{C}}$ DBD, or GST alone and assayed by gel mobility shift assay. GST-FruA DBD and GST-Fru ${ }^{\mathrm{A}}$ DBD bound to oligonucleotides containing their respective consensus sequence (Lane 2 and 8) have slower mobility than GST (Lane 4 and 10), GST-Fru ${ }^{A}$ DBD (Lane 3 and 12), or GST-Fru CBD (Lane 6 and 9) incubated with oligonucleotides containing random sequences or the consensus sequence from other zinc finger domains or free oligonucleotides (no protein added in Lanes 1, 5, 7,11).

over-expression of any of the $\mathrm{Fru}^{\mathrm{M}}$ isoforms in males, there is an enrichment of genes that contain protein domains that function in neuronal patterning and physiology. Among the enriched categories for protein domains are immunoglobulin-like fold, pleckstrin homology domain, PDZ domain, Ion transport domain, epidermal growth factor-like domain, and voltage dependent potassium channel. Many proteins with these domains function at the plasma membrane and mediate neuronal projection patterns, form complexes with channels, and make junctions, including synaptic and neuromuscular junctions, which are consistent with functions ascribed to $\mathrm{Fru}^{\mathrm{M}}$ isoforms (Additional file 5: Table S4).

Among the enriched GO terms for those 1,217 upregulated genes are those that underlie diverse functions in development of the nervous system and adult 
Table 1 Genes containing DNA binding motifs are significantly enriched in all Fru ${ }^{M}$-induced sets of genes in males

\begin{tabular}{|c|c|c|c|c|c|c|c|c|c|}
\hline & & & $\begin{array}{l}\text { Total } \\
\text { Genes }\end{array}$ & $\begin{array}{l}\text { Number of Genes } \\
\text { with Motif }\end{array}$ & $\begin{array}{l}\text { Expected Number } \\
\text { of Genes }\end{array}$ & $\begin{array}{l}\text { Chi-Square } \\
\text { Value }\end{array}$ & $\begin{array}{l}\text { Degrees of } \\
\text { Freedom }\end{array}$ & $\begin{array}{l}\text { Exact P-value } \\
\text { for Chi-Square }\end{array}$ & $\begin{array}{c}\text { Fisher raw } \\
\text { P-value (2-tail) }\end{array}$ \\
\hline \multirow[t]{6}{*}{ Fru $^{A}$ DBD Motif } & \multirow[t]{4}{*}{ Male } & Induced by over-expression of Fru ${ }^{\mathrm{MA}}$ & 14903 & 644 & 473.4123331 & 174.7423677 & 1 & 9.87E-39 & $2.39 \mathrm{E}-45$ \\
\hline & & Repressed by over-expression of Fru ${ }^{\mathrm{MA}}$ & 14903 & 134 & 128.4256861 & 0.66217505 & 1 & 0.42340488 & 0.465483604 \\
\hline & & $\begin{array}{l}\text { Induced by FruM (As determined by } \\
\text { fru P1 mutant analysis) }\end{array}$ & 14903 & 575 & 444.4536 & 108.65168 & 1 & 5.99946E-25 & $8.5546 \mathrm{E}-28$ \\
\hline & & $\begin{array}{l}\text { Repressed by Fru }{ }^{\mathrm{M}} \text { (As determined by } \\
\text { fru P1 mutant analysis) }\end{array}$ & 14903 & 276 & 274.4784272 & 0.023454623 & 1 & 0.880224856 & 0.919841345 \\
\hline & \multirow[t]{2}{*}{ Female } & Induced by over-expression of Fru ${ }^{\mathrm{MA}}$ & 14903 & 80 & 69.87868215 & 3.98687096 & 1 & 0.04846709 & 0.04846709 \\
\hline & & Repressed by over-expression of Fru ${ }^{\mathrm{MA}}$ & 14903 & 116 & 115.2053949 & 0.014977928 & 1 & 0.9387153 & 0.938715296 \\
\hline \multirow[t]{6}{*}{ Fru $^{B}$ DBD Motif } & \multirow[t]{4}{*}{ Male } & Induced by over-expression of Fru ${ }^{\mathrm{MB}}$ & 14903 & 378 & 183.7706502 & 287.4837937 & 1 & $3.99 \mathrm{E}-56$ & $6.65 \mathrm{E}-56$ \\
\hline & & Repressed by over-expression of Fru ${ }^{\mathrm{MB}}$ & 14903 & 50 & 64.40676374 & 4.36503163 & 1 & 0.041977653 & 0.035594233 \\
\hline & & $\begin{array}{l}\text { Induced by Fru }{ }^{\mathrm{M}} \text { (As determined by } \\
\text { fru P1 mutant analysis) }\end{array}$ & 14903 & 309 & 175.564383 & 141.6955672 & 1 & 2.20046E-29 & $3.27561 \mathrm{E}-29$ \\
\hline & & $\begin{array}{l}\text { Repressed by Fru }{ }^{\mathrm{M}} \text { (As determined by } \\
\text { fru P1 mutant analysis) }\end{array}$ & 14903 & 128 & 108.4221969 & 4.847043913 & 1 & 0.028457111 & 0.032441531 \\
\hline & \multirow[t]{2}{*}{ Female } & Induced by over-expression of Fru ${ }^{\mathrm{MB}}$ & 14903 & 35 & 29.09494733 & 1.607773993 & 1 & 0.236941316 & 0.199286144 \\
\hline & & Repressed by over-expression of Fru ${ }^{\mathrm{MB}}$ & 14903 & 64 & 58.93591894 & 0.588511944 & 1 & 0.448926212 & 0.44892621 \\
\hline \multirow[t]{6}{*}{$\mathrm{Fru}^{\mathrm{C}} \mathrm{DBD}$ Motif } & \multirow[t]{4}{*}{ Male } & Induced by over-expression of Fru ${ }^{\mathrm{MC}}$ & 14903 & 296 & 131.8687513 & 253.964127 & 1 & $3.55 \mathrm{E}-46$ & $4.53 \mathrm{E}-46$ \\
\hline & & Repressed by over-expression of Fru ${ }^{\mathrm{MC}}$ & 14903 & 33 & 28.16614105 & 0.261120798 & 1 & 0.613295999 & 0.613295997 \\
\hline & & $\begin{array}{l}\text { Induced by FruM (As determined by } \\
\text { fru P1 mutant analysis) }\end{array}$ & 14903 & 209 & 100.4307858 & 143.6364162 & 1 & $2.29794 \mathrm{E}-27$ & $2.78422 \mathrm{E}-27$ \\
\hline & & $\begin{array}{l}\text { Repressed by Fru }{ }^{\mathrm{M}} \text { (As determined by } \\
\text { fru P1 mutant analysis) }\end{array}$ & 14903 & 62 & 62.0224116 & 9.72597E-06 & 1 & 1 & 1 \\
\hline & \multirow[t]{2}{*}{ Female } & Induced by over-expression of Fru ${ }^{\mathrm{MC}}$ & 14903 & 30 & 23.75629068 & 1.934825144 & 1 & 0.180129952 & 0.180129951 \\
\hline & & Repressed by over-expression of Fru ${ }^{\mathrm{MC}}$ & 14903 & 33 & 28.08642555 & 0.980189811 & 1 & 0.355875025 & 0.306776226 \\
\hline
\end{tabular}


physiological functions. The Biological Process GO terms include axon guidance, regulation of response to stimulus, regulation of neuron differentiation and behavior, among many others. The Cellular Component GO terms include synapse, ion channel and neuromuscular junction, among many others (for a complete list see Additional file 5: Table S4).

In contrast, an analysis of the 554 genes downregulated by over-expression of any of the $\mathrm{Fru}^{\mathrm{M}}$ isoforms in males revealed an enrichment of genes that contain protein domains that function in lipid and triglyceride metabolism, consistent with previous studies [30-32] (Additional file 5: Table S4).

An analysis of the genes induced by overexpression of $\mathrm{Fru}^{\mathrm{M}}$ in females identified fewer significantly enriched GO Biological Process categories, as compared to our observations in males. These include response to caffeine, response to purines, and potassium ion transport. The GO category male sex differentiation is included, but only contains $d s x$ and fru. Nearly all the enriched GO Biological Process categories identified in the genes repressed by $\mathrm{Fru}^{\mathrm{M}}$ in females include defense response genes (Additional file 5: Table S4).

Genes that are up regulated in response to overexpression of $\mathrm{Fru}^{\mathrm{M}}$ isoforms include those that were previously implicated in playing a role in fru P1 expressing neurons, including the ecdysone receptor gene $E c R$ and the ecdysone hierarchy gene broad [33]. Several neuronally-expressed genes, not previously known to be regulated by $\mathrm{Fru}^{\mathrm{M}}$ isoforms, were identified that play critical roles in axon target recognition and attraction, axon guidance, dendrite guidance axon defasiculation, and sensory perception. These genes include roundabout (1 and 3), Dscam (1,2,3 and 4), prospero, semaphorin (1a, 2a), Netrin $A$ and B, fasiclin (I and II), Notch, Cadherin N, Gustatory receptor $93 a$ and abnormal chemosensory jump 6, Gaba receptor, serotonin receptor, nicotinic Acetylcholine Receptor alpha 7E, Neuroligin 1, foxo, Target of rapamycin, cacophony, muscarinic Acetylcholine Receptor 60C, spinster, and Dopamine receptor 2, among many genes.

An analysis of the genes induced in response to the expression of $\mathrm{Fru}^{\mathrm{M}}$ isoforms reveals that a large fraction of these genes had previously been shown to have high expression in nervous system tissues. Thus of the genes with induced expression in response to $\mathrm{Fru}^{\mathrm{M}}$ isoform expression, 649, 645 and 592 genes were previously shown to be significantly highly expressed in the adult brain, larval brain and adult ventral nerve cord, respectively, when compared to Flyatlas data using the Flymine portal $[28,34]$. Of the tissues examined in the Flyatlas study, these three tissues had the largest overlap of genes with significantly high expression with the genes induced by $\mathrm{Fru}^{\mathrm{M}}$ from this study.

\section{Comparison of differential gene expression in response to $\mathrm{Fru}^{\mathrm{M}}$ over-expression vs. Fru ${ }^{\mathrm{M}}$ loss of function}

We have also analyzed gene expression differences in head tissues of fru P1 mutant males as compared to wild type males to further confirm our over-expression analysis. Over-expression of $\mathrm{Fru}^{\mathrm{M}}$ is likely to yield higher folddifferences in gene expression than observed in the loss-offunction mutants, because the absolute difference in fru P1 mRNA amounts is greater between over-expressor flies and wild type flies than between loss-of-function fru P1 flies and wild type flies based on RNA-seq data. Thus, we identified genes based on significant differences in expression between fru P1 mutants and wild type males, but did not require a $\geq 2$ fold change.

Based on the loss-of-function analyses, of the 706 genes that are induced by $\mathrm{Fru}^{\mathrm{M}}, 209$ genes were also induced by at least one of the $\mathrm{Fru}^{\mathrm{M}}$ isoforms in the overexpression experiments. If we do not restrict the list of genes to those with $\geq 2$-fold induction by overexpression of at least one of the $\mathrm{Fru}^{\mathrm{M}}$ isoforms, 360 genes were identified as induced by $\mathrm{Fru}^{\mathrm{M}}$ in both the loss-of-function and overexpression experiment. Of the 436 genes that are repressed by $\mathrm{Fru}^{\mathrm{M}}$, 19 genes were also repressed by at least one of the $\mathrm{Fru}^{\mathrm{M}}$ isoforms in the overexpression experiments (Additional file 2: Figure S1 and Additional file 6: Table S5). There is a significant association between the lists of genes that we identified as regulated downstream of fru $P 1$ in the loss-of-function analyses to those identified in the overexpression analyses $(p<0.05)$.

The genes induced by fru P1 in the fru P1 loss-of-function analysis have a significant enrichment of genes that contained either the $\mathrm{Fru}^{\mathrm{A}}$, $\mathrm{Fru}^{\mathrm{B}}$ or $\mathrm{Fru}^{\mathrm{C}}$ binding sites motif, whereas those that are repressed downstream of fru P1 show an enrichment of only the $\mathrm{Fru}^{\mathrm{B}}$ binding site motif (Table 1). Taken together, these results further support the idea that genes that are induced downstream of $\mathrm{Fru}^{\mathrm{M}}$ isoform are likely direct targets.

\section{Genes that are regulated downstream of $\mathrm{Fru}^{\mathrm{M}}$ isoforms do not have the expected chromosome distribution}

An examination of the chromosomal distribution of the genes with exons that are either induced or repressed downstream of $\mathrm{Fru}^{\mathrm{M}}$ isoforms in the male over-expression experiments revealed a significant enrichment and depletion on the $\mathrm{X}$ chromosome, respectively. The genes with up-regulated expression downstream of $\mathrm{Fru}^{\mathrm{M}}$ isoforms in males are enriched on the $\mathrm{X}$ chromosome and the second chromosome (Figure 4 and Additional file 7: Table S6). The genes with reduced expression downstream of $\mathrm{Fru}^{\mathrm{M}}$ isoforms are significantly depleted from the $\mathrm{X}$ chromosome. In addition, if we examine the genes that are induced by $\mathrm{Fru}^{\mathrm{M}}$ that were previously shown to be significantly highly expressed in the adult brain, larval brain or adult ventral nerve cord these genes sets are present on the $\mathrm{X}$ 

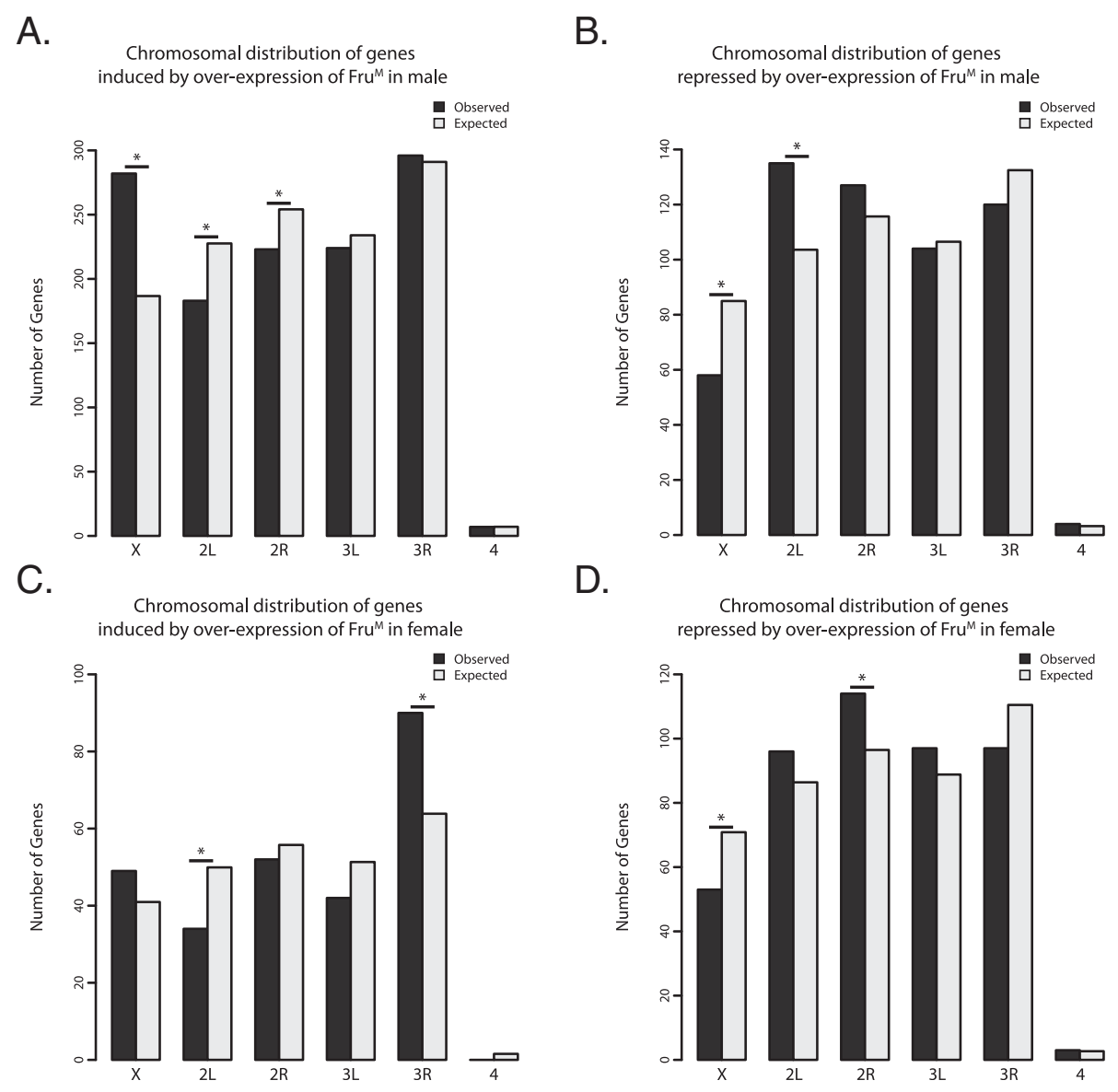

D.

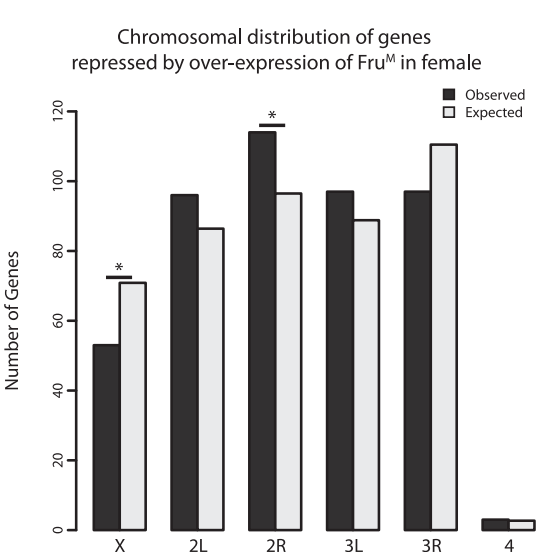

Figure 4 Chromosomal distributions of genes regulated by Fru ${ }^{\mathrm{M}}$. (A-D) Observed (black) and expected (grey) number of genes on each chromosome for the sets of genes induced and repressed by over-expression of Fru ${ }^{\mathrm{MA}}$, Fru ${ }^{\mathrm{MB}}$, and $\mathrm{Fru}^{\mathrm{MC}}$ in males or females. Asterisks indicate significant enrichment or depletion between observed and expected (Fisher's exact test, $\mathrm{p}$-value $<0.05$ ).

chromosome at a higher level than expected, based on Flyatlas data using the Flymine portal [28,34]. These results suggest that the $\mathrm{X}$ chromosome has properties distinct from the autosomes with respect to genes important for the potential for male courtship behaviors.

\section{Discussion}

In this study we identified hundreds of genes regulated downstream of $\mathrm{Fru}^{\mathrm{M}}$ isoform activity. $\mathrm{Fru}^{\mathrm{MA}}$, $\mathrm{Fru}^{\mathrm{MB}}$ and $\mathrm{Fru}^{\mathrm{MC}}$ have differences in the gene sets induced or repressed when they are over-expressed, demonstrating that each isoform has distinct biochemical activities (Figure 2). Consistent with this observation is that each $\mathrm{Fru}^{\mathrm{M}}$ isoform has different DNA binding specificity (Figure 3). Our results suggest that there are sex-specific factors that influence $\mathrm{Fru}^{\mathrm{M}}$ isoform activity, as over-expression of $\mathrm{Fru}^{\mathrm{MA}}$, $\mathrm{Fru}^{\mathrm{MB}}$ and $\mathrm{Fru}^{\mathrm{MC}}$ isoforms in males and females resulted in different genes that are induced and repressed by each isoform (Figure 2 and Additional file 2: Figure S1). The gene sets identified as induced downstream of $\mathrm{Fru}^{\mathrm{M}}$ isoforms in males are enriched with genes with nervous system function, based on GO annotations (Additional file 5: Table S4).

Additionally, it is worth noting that there may be other possible sources for the differences observed in the gene expression levels in these experiments. First, the $\mathrm{Fru}^{\mathrm{M}}$ proteins contain a BTB domain that in previous work has been shown to contain a dimerization domain that can mediate homodimeric or heterodimeric interactions. Thus, some of the effects we observe could be due to 1) differences in the stoichiometric ratios of $\mathrm{Fru}^{\mathrm{M}}$ with each other, and/or 2) differences in the stoichiometric ratios of $\mathrm{Fru}^{\mathrm{M}}$ with other potential dimerization partners. However, based on immunofluorescence results we do not observe substantially different levels of over-expression of each isoform, nor is there substantial expression, if any, outside of the normal fru P1 expression pattern (see Additional file 8: Figure S2). Second, there is a significant association between the genes that are either induced or repressed when $\mathrm{Fru}^{\mathrm{M}}$ is over-expressed, with those genes identified in loss-of-function $\mathrm{fru}^{\mathrm{M}}$ mutant analyses, demonstrating the physiological relevance of the 
genes identified by over-expression. Third, there is significant enrichment of the binding site sequences identified for each isoform within the genes that are induced by each isoform. Fourth, while our criteria were stringent (significant and substantial differences from two different wild type strains), strain differences may account for some of the differences between wild type male and female and $\mathrm{Fru}^{\mathrm{M}}$ over-expressor male and female strains, respectively. However, such strain differences are not likely to account for the differences we observe between the $\mathrm{Fru}^{\mathrm{M}}$ isoforms, which are in the same genetic background, nor can strain differences account for differences observed across sex. Taken together, these results demonstrate that in context of the over-expression experiments each of the three $\mathrm{Fru}^{\mathrm{M}}$ isoforms examined has different activities with respect to genes that are induced or repressed in males, with many more genes having induced rather than repressed expression in males.

In previous studies, production of $\mathrm{Fru}^{\mathrm{M}}$ in females, by expression of a tra-2 RNAi transgene in fru P1-expressing neurons, was sufficient to endow females with the potential to perform the first four sub-steps of the male courtship ritual, following, tapping, wing extension and proboscis extension, but not attempted copulation [14]. In contrast, overexpression of $\mathrm{Fru}^{\mathrm{MA}}$ or $\mathrm{Fru}^{\mathrm{MC}}$ in fru P1-expressing neurons, resulted in flies that displayed only following and tapping reviewed in [4], suggesting that overexpression of $\mathrm{Fru}^{\mathrm{M}}$ in females is not sufficient to endow females with the potential to perform courtship behaviors. The 42 genes identified as induced by all three $\mathrm{Fru}^{\mathrm{M}}$ isoforms in females will be interesting to examine, with respect to their role in establishing the potential for these early courtship steps. Interestingly, one of these genes is $\operatorname{Ir} 54 a$, which encodes a member of a diverse family of ionotropic receptors, some of which are expressed in the adult antenna and underlie chemosensory functions [35]. It is also known that $\mathrm{Dsx}^{\mathrm{M}}$ plays a role in establishing the potential for courtship behaviors [26,27,36-38], which would not have been present in females in which $\mathrm{Fru}^{\mathrm{M}}$ was produced, though $\mathrm{Dsx}^{\mathrm{M}}$ is not present in all fru P1-expressing neruons, so is unlikely to account for all the differences between males and females observed here [26,37]. Our results may further explain why there was not a complete rescue of male courtship behavior. It is clear that the sex of the fly in which $\mathrm{Fru}^{\mathrm{M}}$ is produced has an impact on the genes that are induced and repressed. These results suggest that there are additional sex-specific factors that influence $\mathrm{Fru}^{\mathrm{M}}$ activity, which may include Dsx ${ }^{\mathrm{M}}$. Further biochemical characterization of $\mathrm{Fru}^{\mathrm{M}}$ protein interactions will be important to understand $\mathrm{Fru}^{\mathrm{M}}$ activities.

While fru has been predicted to be a transcription factor based on the observation that fru encodes BTB-zinc finger products, no direct transcriptional targets of fru have been identified, leaving this an open question. A recent study has shown that $\mathrm{Fru}^{\mathrm{M}}$ associates with a cofactor, Bonus, and subsequently associates with two chromatin modifying proteins, HP1a and HDAC1, however it was not clear if the association of $\mathrm{Fru}^{\mathrm{M}}$ with chromatin was direct [20]. The results presented here demonstrate that $\mathrm{Fru}^{\mathrm{M}}$ can bind DNA and that three $\mathrm{Fru}^{\mathrm{M}}$ isoforms examined have different binding activities. Given our observation that the binding sites are significantly enriched in all gene sets identified as induced, but not repressed by $\mathrm{Fru}^{\mathrm{M}}$, suggests that $\mathrm{Fru}^{\mathrm{M}}$ may function by binding enhancer DNA directly, but acts in an indirect manner to repress gene expression (Table 1).

In previous studies we and others have show that genes with male-biased expression were enriched on the $\mathrm{X}$ chromosome in the adult head [31,39] and brain [40]. There was also a significant enrichment of genes with male-biased expression that reside near dosage compensation entry sites $[39,40]$. Here, we observe significant enrichment of genes that reside on the $\mathrm{X}$ chromosome that are induced by $\mathrm{Fru}^{\mathrm{M}}$ in males. This observation supports the idea that over evolutionary time there may have been a selection for genes with male-specific functions to reside on the $\mathrm{X}$ chromosome and in particular those regulated by $\mathrm{Fru}^{\mathrm{M}}$. Perhaps, $\mathrm{Fru}^{\mathrm{M}}$ isoforms and their gene targets have evolved to take advantage of the unique properties of the male nucleus. These differences include the dosage compensation complex that is bound to the male $\mathrm{X}$ chromosome that leads to less compact chromatin reviewed in [41], the presence of the Y chromosome that affects chromatin architecture throughout the nucleus [42], or other differences in the chromatin and three-dimensional architecture of the nucleus in males [for example see 43]. It is possible that there are more interconnections in the sex hierarchy model between chromosomal sex, the sex hierarchy branches and sexual development that is downstream of $\mathrm{Fru}^{\mathrm{M}}$ than shown in the model (Figure 1).

\section{Conclusions}

The results in this study add to the information regarding $\mathrm{Fru}^{\mathrm{M}}$ function with the identification of hundreds of genes regulated by $\mathrm{Fru}^{\mathrm{M}}$, many of which have known roles in nervous system development and physiology. One of the next exciting challenges to our understanding of how complex behaviors are specified at a moleculargenetic level will be to develop tools to interrogate the functions of specific transcript isoforms in a cell-specific manner.

\section{Methods}

\section{Flies}

Flies were raised on standard cornmeal food medium at $25^{\circ} \mathrm{C}$ on a 12 hour light and 12 hour dark cycle. Wild type flies were the Canton-S (CS) and Berlin strains. 
Transheterozygous mutants for fru $P 1$ are $D f(3 R) P 14 / D f$ (3R)fru $u^{4-40}$ and $f r u^{w 12} / D f(3 R) C h a^{M 5}$, which are phenotypically void of all male courtship behaviors [10]. In addition, no detectable fru $P 1$ transcript or $\mathrm{Fru}^{\mathrm{M}}$ protein is present in $D f(3 R) P 14 / D f(3 R) f r u^{4-40}$ [11], and no full length fru P1 mRNAs are present in $f r u^{w 12} / D f(3 R) C h a^{M 5}$ [10]. Df(3R)P14 contains a breakpoint in fru extending proximally removing common fru coding exons and ending in the cytological location 90C2-D1 [5]; Df(3R)fru ${ }^{4-40}$ contains a breakpoint in fru extends distally thus removing the fru P1 promoter [11]; $f r u^{w 12}$ is an inversion-cum-translocation that removes P1-3 from common fru coding exons [10]; and $D f(3 R) C h a^{M 5}$ contains a breakpoint between $P 1$ and $P 2$ that extends distally removing $P 1$ ending in the cytological location 91D [5,10]. The fru P1-Gal4, UAS-Fru ${ }^{M A}$, $U A S-F r u^{M B}$, and $U A S-F r u^{M C}$ were described previously [14,44]. $y^{1} w^{1118} ; P($ UAS-Gal4.H)12B stock was obtained from Bloomington stock center.

Flies that ectopically expressed $\mathrm{Fru}^{\mathrm{M}}$ isoforms were of the genotypes $y w /(w$ or $\mathrm{Y}) ; P\left(w^{+m C}\right.$, UAS-Gal4 $) / P\left(w^{+m C}\right.$, UAS-Fru ${ }^{M A},{ }^{B}$, or ${ }^{C}$ ); fru P1-Gal4/+. While each UAS$\mathrm{Fru}^{\mathrm{M}}$ transgene is inserted at a different location, they are homozygous viable and each respective DNA binding domain (A, B, and $\mathrm{C}$ ) encoding exon is $>$ four-fold induced compared to wild type in our over-expression assay conditions, by examining the RNA-seq expression data. Immunofluorescence using an antibody specific to the male-specific region common to all $\mathrm{Fru}^{\mathrm{M}}$ proteins demonstrates relatively similar levels of the male-specific proteins in fru P1-Gal4 expressing neurons and is not readily detectable in other regions of the CNS (Additional file 8: Figure S2). Additionally, examination of male-female courtship of the above transgenic strains demonstrated that over-expression is not changing male behaviors significantly (Additional file 9: Figure S3).

\section{Tissue collection}

Adult head cDNA libraries were prepared from three independent biological replicates from each of the following genotypes: 1) from males and females: Canton S, Berlin, $y w /$ $(w$ or $\mathrm{Y}) ; P\left(w^{+m C}\right.$, UAS-Gal4 $) / P\left(w^{+m C}, U A S-F r u^{M A}\right) ; f r u$ P1-Gal4/+, $y w /(w$ or Y $) ; P\left(w^{+m C}\right.$, UAS-Gal4 $) / P\left(w^{+m C}\right.$, UAS-Fru $\left.{ }^{M B}\right) ;$ fru P1-Gal4/+, y $w /(w$ or $\mathrm{Y}) ; P\left(w^{+m C}\right.$, UASGal4)/P( $\left.w^{+m C}, U A S-F r u^{M C}\right) ;$ fru P1-Gal4/+ and 2) in males only: $D f(3 R) P 14 / D f(3 R) f r u^{4-40}$ and, $f r u^{w 12} / D f(3 R) C h a^{M 5}$ males. For each experimental condition, approximately 200 flies that were 8 to 24 hours post-eclosion were used. All flies were collected 0 to 16 hours post-eclosion under anesthetization and allowed to recover for 8 hours before being snap frozen in liquid nitrogen. Snap frozen whole animals were stored at $-80^{\circ} \mathrm{C}$ until heads were collected. Adult heads were separated from bodies by mechanical tapping of the cryovial. A piece of plastic was cooled on dry ice, on which the frozen heads were separated from the bodies and immediately transferred and homogenized in $1 \mathrm{~mL}$ of TRIzol ${ }^{\circledR}$ (Invitrogen).

\section{Illumina sequencing library preparation}

Total RNA was extracted using TRIzol ${ }^{\circledR}$ Reagent (Invitrogen), and RNA was precipitated by addition of $250 \mu \mathrm{L} 100 \%$ isopropanol and $250 \mu \mathrm{L} 1.2 \mathrm{M} \mathrm{NaCitrate,}$ $0.8 \mathrm{M} \mathrm{NaCl}$ in DEPC-treated $\mathrm{H}_{2} \mathrm{O}$. Approximately $25 \mu \mathrm{g}$ total RNA was DNase treated to remove any trace amounts of DNA, following Zymo Research RNA Clean \& Concentrator ${ }^{\mathrm{Tm}}-25$ In-Column DNase Digestion protocol, using 10 units Ambion ${ }^{\circledR}$ TURBO $^{\mathrm{mm}}$ DNase. Poly $(\mathrm{A})+$ transcripts were subsequently isolated from total RNA using Ambion $^{\circledR}$ MicroPoly(A)Purist ${ }^{\mathrm{m}}$ Kit. 100 ng mRNA was chemically fragmented to a range of approximately 200-500 base pairs using the Ambion ${ }^{\circledR}$ RNA Fragmentation Reagent, and the reaction was cleaned using Zymo Research RNA Clean \& Concentrator ${ }^{\mathrm{m}}-5$. First strand cDNA was synthesized using SuperScript ${ }^{\circledR}$ II Reverse Transcriptase (Invitroge $^{\mathrm{Tm}}$ ) and a combination of $3 \mu \mathrm{g}$ random hexamers and $0.15 \mu \mathrm{g}$ oligo $(\mathrm{dT})_{20}$ primers. Following first strand synthesis, the second strand of the cDNA was synthesized by addition of DNA polymerase I $\left(\right.$ Invitrogen $^{\mathrm{m}} \mathrm{)}$ ), RNase $\mathrm{H}$ (New England Biolabs ${ }^{\circledR}$ Inc.), dNTPs and second strand buffer $\left(\right.$ Invitrogen $\left.^{\mathrm{TN}}\right)$. This reaction and all subsequent reactions were cleaned using Zymo Research DNA Clean \& Concentrator $^{\text {rm }}-5$ kit. Double stranded cDNA templates were blunt ended using End-It ${ }^{\mathrm{Tm}}$ Repair Kit (Epicentre ${ }^{\circledR}$ ). Next, A-overhangs were then added to both ends with Klenow fragment $\left(3^{\prime} \rightarrow 5^{\prime}\right.$ exo-minus) (New England Biolabs ${ }^{\circledR}$ Inc.). Illumina sequencing adapters were then ligated to both ends of the cDNA templates using FastLink $^{\mathrm{mm}}$ DNA Ligation Kit (Epicentre $\left.{ }^{\circledR}\right)$. cDNA templates were then amplified by performing polymerase chain reaction (PCR; 18 cycles) that extended the adapter and incorporated a different six base pair index into each sample. The product was then isolated by gel purification of 250550 base pair fragments. Samples were then pooled and sequenced on the Illumina Genome Analyzer GAII platform with 72 base pair single end reads, and the reads were matched to their corresponding sample via the index.

\section{SELEX}

Each of the three fru DNA binding domain (DBD) encoding sequences were PCR amplified from fru cDNAs using the following primer pairs that contain $E c o R 1$ or XhoI restriction sites engineered at their ends: $\mathrm{Fru}^{\mathrm{MA}}$ primers are 5'CCGGAATTCCGC GTCAAGTGTTTTA ACATTAAGC and 5'CCGCTCGAGGTTTGCTTGATT CTTGGTTACTTA; Fru ${ }^{\mathrm{MB}}$ primers are 5'GGC CGGAA TTCTCCAAGGCCTGGCACATG and 5' CCCGCTCG AGTGTGCTG CTGTTGCTGC; $\mathrm{Fru}^{\mathrm{MC}}$ primers are 5' CCGGAATTCCAGCAGCGCCCGCCACC and 5'GCCG CTCGAGCGGGATGGGCTGCACTTGGGC. For each 
DBD-encoding exon, the first primer has the EcoR 1 site and the second primer has the XhoI site. The primers were designed to amplify beginning where the divergent sequence for each Fru isoform begins (see Figure 1), and the amplicon includes each isoforms respective stop codon at the end. Each region was cloned as in-frame fusions with Glutathione S-transferase at the amino terminus (GST-Fru), into the pGEX-4 T1 plasmid for expression in bacteria.

Each DBD containing plasmid was transformed into E.coli BL21 and single colonies were grown to $\sim \mathrm{OD}_{600}=$ 0.8 when IPTG was added to $0.1 \mathrm{mM}$ to induce protein expression. Bacteria were grown for approximately two more hours in the presence of IPTG and then harvested by centrifugation at $8,000 \mathrm{rpm}$ for 10 minutes. Protein extract was made by resuspending a $200 \mathrm{~mL}$ culture in $10 \mathrm{~mL}$ of ice cold Buffer 1 (100 mM KCl, $50 \mathrm{mM} \mathrm{HEPES,} \mathrm{pH} \mathrm{7.5,}$ $10 \%$ glycerol, $5 \mathrm{mM} \mathrm{MgCl}$, $1 \mathrm{mM} \mathrm{DTT}$ and protease inhibitors). The cells were lysed on ice by sonication and were visually monitored with a compound microscope to assess the efficiency of sonication. Lysates were cleared by centrifugation and the supernatant was retained. Fusion proteins were purified by binding to $\sim 500 \mu \mathrm{L}$ of a $50 \%$ slurry of glutathione Sepharose 4B that had been washed and equilibrated in Buffer 1. The protein was mixed with the Sepharose resin for 2 hour at $4^{\circ} \mathrm{C}$ and then loaded into a gravity flow column. The protein bound to the Sepharose was washed with 5 column volumes of Buffer 1 . For the SELEX, the Sepharose beads with the bound purified protein was resuspended in $250 \mu \mathrm{L}$ Buffer $2(100 \mathrm{mM} \mathrm{KCl}$, $50 \mathrm{mM}$ HEPES, pH 7.5, 50\% glycerol, $5 \mathrm{mM} \mathrm{MgCl}_{2}, 1 \mathrm{mM}$ DTT) and stored at $4{ }^{\circ} \mathrm{C}$. For gel shifts, the protein was eluted with glutathione by incubating the slurry for two hours in elution buffer (10 mM glutathione in $50 \mathrm{mM}$ Tris, $\mathrm{pH}$ 8.0) and dialyzed into Buffer 1. Examination of protein by SDS-PAGE and Commassie staining showed a high degree of purity and proteins of the expected sizes.

The SELEX procedure was performed as previously described with some modification [24]. Here we used oligoR76: CAGGTCAGTTCAGCGGATCCTGTCGN 26 GAGGCGAATTCAGTGCAACTGCAGC, primer F GC TGCAGTTGCACTGAATTCGCCTC and primer R CA GGTCAGTTCAGCGGATCCTGTCG. For the first round of the SELEX procedure, a complementary strand of OligoR76 was generated by a single cycle of PCR using primer F, $100 \mathrm{ng}$ of OligoR76 in a $20 \mu \mathrm{L}$ PCR reaction to generate double stranded molecules $\left(1\right.$ minute at $94^{\circ} \mathrm{C}$, 3 minutes at $62^{\circ} \mathrm{C}, 9$ minutes at $72^{\circ} \mathrm{C}$ ). The first round of SELEX was performed with $5 \mu \mathrm{L}$ of the primer extension oligoR76 DNA reaction, $20 \mu \mathrm{L}$ of the GST-Fru/bead slurry and $100 \mu \mathrm{L}$ of Buffer 3 (Buffer 1 with poly dI,dC $4 \mu \mathrm{g} / \mu \mathrm{L}$ and BSA $40 \mu \mathrm{g} / \mathrm{mL}$ ) for 2 hours at $4^{\circ} \mathrm{C}$. The protein/bead slurry was washed twice with $800 \mu \mathrm{L}$ Buffer 1 and then was resuspended in $30 \mu \mathrm{L}$ of high quality water, boiled for 2 minutes and the supernatant that included the bound DNA retained. For the next nine rounds of SELEX, $10 \mu \mathrm{L}$ of the eluted DNA from each preceding round was used in a $100 \mu \mathrm{L}$ PCR reaction for 20 cycles, using primers $\mathrm{F}$ and $\mathrm{R}$. The DNA was loaded onto a $2 \%$ Nuseive gel and separated by electrophoresis. The DNA band at 75 base pairs was excised and purified using Qiaquick gel extraction columns (Qiagen). For the last rounds of the SELEX, $1 \mu \mathrm{L}$ of the purified DNA from the previous round $(\sim 300 \mathrm{ng})$ was mixed with $20 \mu \mathrm{L}$ of the protein/bead slurry in $100 \mu \mathrm{L}$ Buffer 3 . The bound DNA fragments were purified as described for round 1 of the SELEX. After the tenth round of the SELEX, the DNA fragments were cloned by ligation into Bluescript at the EcoRI and BamHI sites and sequenced by Sanger sequencing. For each Fru DBD, at least 20 independent clones were sequenced. A Gibbs sampling algorithm was used to find the consensus motif [45]. For $\mathrm{Fru}^{\mathrm{MB}}$ a sequence of low complexity was identified from the first SELEX experiment and so a second full SELEX experiment was performed, each with 10 rounds of selection. Nearly the same consensus sequence was identified in both rounds, providing confidence in the result.

To determine if the motifs identified in the SELEX bind specifically to the DNA binding domain used in the SELEX procedure, gel shift reactions were performed using annealed phosphorylated oligonucleotides that contain common flanking DNA sequence chosen to facilitate cloning and either the binding sequences identified in the SELEX (in bold below), or oligonucleotides of the same nucleotide content but randomized but in the same position as the identified binding site resides in the sequence (in italic and bold below). For $\mathrm{Fru}^{\mathrm{MA}}$ the oligonucleotide sequences were 5'TCGACCTGCAGAGTAACCTG CAGG and 5'TCGACCTGCAGGTTACTCTGCAGG. The $\mathrm{Fru}^{\mathrm{MA}}$ randomized sequences were 5'TCGACCT GCAGATAGACCTGCAGG and 5'TCGACCTGCAG GTCTATCTGCAGG. For $\mathrm{Fru}^{\mathrm{MC}}$ the oligonucleotide sequences were 5'TCGACCTGCAGTGTTACATCAC TGCAGG and 5'TCGACCTGCAGTGATGTAACAC TGCAGG. The Fru ${ }^{\mathrm{MC}}$ randomized sequences were 5' TCGACCTGCAGGCATCTATATCTGCAGG and 5'TC GACCTGCAGATATAGATGCCTGCAGG. Gel shift reactions were performed as previously described [46].

For $\mathrm{Fru}^{\mathrm{MB}}$, two independent trials with ten rounds of selection for the $\mathrm{Fru}^{\mathrm{MB}}$ binding motif identified very similar sequences. The consensus sequence for $\mathrm{Fru}^{\mathrm{MB}}$ from the two independent trials is GCCCTTT. The GST-Fru ${ }^{\mathrm{B}}$ protein bound DNA in the invariant region present in all the synthesized oligos (see above). To determine if the binding site identified for $\mathrm{Fru}^{\mathrm{MB}}$ was correct, a modified assay was performed in test tubes. In this assay $5 \mu \mathrm{L}$ of $\mathrm{P}^{32}$ labeled DNA from the first and tenth round of the SELEX procedure were mixed with 
$30 \mu \mathrm{L}$ of the Fru ${ }^{\mathrm{MB}}$ protein/bead slurry in $150 \mu \mathrm{L}$ Buffer 3 for two hours at $4^{\circ} \mathrm{C}$, washed three times in Buffer 1 and added to $5 \mathrm{~mL}$ of scintillation fluid. The percent of the input retained from the first and tenth SELEX round was quantified using a scintillation counter. The $\mathrm{P}^{32}$ labeled DNA was generated by a standard PCR reaction, using Primer F and R, $1 \mu \mathrm{L}$ of DNA from the SELEX round, and included dATP-P ${ }^{32}$ gamma. Only $0.8 \%$ of the labeled input DNA from the first round of SELEX was retained on the $\mathrm{Fru}^{\mathrm{MB}}$ protein/bead slurry, whereas $3.6 \%$ was retained from the tenth round of SELEX, demonstrating that the SELEX enriched for a sequence bound by $\mathrm{Fru}^{\mathrm{MB}}$.

\section{Illumina read mapping}

We used a sequential mapping pipeline that mapped approximately $95 \%$ of all reads to the Drosophila genome. Barcode, primer, and adapter sequences were trimmed. Reads were aligned to the $D$. melanogaster genome FB5.30 (FlyBase v5.30) using Bowtie (-tryhard, --best, -strata, -m1) [47], unaligned reads were 3' end quality trimmed and homopolymers (5+) were removed. Quality trimmed reads were mapped as above. Unaligned reads at this step were aligned to junctions estimated by Tophat [48]. Any remaining unaligned reads were mapped allowing for gaps to FB5.30 using LAST [49]. Reads were visualized as wiggle tracks on FB5.30 genome using a custom R script [25].

Within a gene, exons from different isoforms may overlap due to alternative start and end positions (Additional file 10: Figure S4). Exons from different genes may also overlap. Overlapping exons, regardless of strand, were combined into the maximum exonic region see [25]. If there was a single exon in the region it was labeled as S\#\#\#\#SI and if there were multiple overlapping exons, they were combined and labeled as F\#\#\#\#SI (Additional file 10: Figure S4). Exonic regions can be further classified as constitutive (a single exon present in all isoforms), common (exonic region present in all isoforms), and alternative (not present in all isoforms) (Additional file 10: Figure S4). Expression was quantified for each exon in FB5.30 using a perl script. In regions where exons overlap, exons were combined. Of the 60,291 exonic regions 53,459 did not overlap with any other exon. Most overlaps are due to alternate start or end positions $(4,503)$. About 30\% (2,329) are due to exonic regions from different genes, these regions were not considered further. We considered an exonic region as detected if at least one read mapped to that region. Exonic regions with no reads mapping for any observed samples were not considered further $(1,550$ regions). For each exonic region, Reads Per Kilobase per Million mapped reads RPKM [50] was calculated and the natural $\log$ taken. If no variation was observed in one condition, or if it was not detected at least once in each treatment group no statistical analysis is possible. These 11,104 regions and the remaining 45,339 exonic regions that were analyzed for quantitative differences in expression are reported in Additional file 11: Table S7.

\section{Differential expression}

A linear model was fit for each exonic region separately and models were examined for conformation to assumptions. All comparisons were performed as contrasts in a single model and a single FDR correction was performed for all contrast simultaneously [51]. Results were partitioned into induced or repressed based upon the direction of the observed difference. To declare that an exon was significantly differentially expressed, we required that exons be both (1) statistically significantly different [False Discovery Rate (FDR) p-value $<0.20$ ] and (2) have a $\geq 2$ fold change in expression level (Additional file 1: Table S1 and Additional file 3: Table S2). We also provide the full lists of genes that have exons that are significantly differentially expressed (Additional file 12: Tables S8 and Additional file 13: Table S9). To reduce the chances of identifying exons only due to background differences in strain, we required that the $\mathrm{Fru}^{\mathrm{M}}$ be different from both wild type backgrounds in order to be declared differentially expressed. For the fru null comparisons, we required that both fru allele combinations were each statistically different from CS and Berlin (four statistical comparisons).

\section{Enrichments and motif analysis}

Enrichments for chromosomal locations were tested by constructing contingency tables and conducting a Fisher's exact test [52]. Position weight matrices (PWMs) generated by SELEX enrichment, were used to identify the locations of $\mathrm{Fru}^{\mathrm{MA}}$, $\mathrm{Fru}^{\mathrm{MB}}$, or $\mathrm{Fru}^{\mathrm{MC}}$ binding sites. MAST [53] was used to identify putative binding sites in a region that included the gene of interest and $2 \mathrm{~kb}$ upstream of the transcription start site, $2 \mathrm{~kb}$ downstream of the 3' UTR and throughout the entire genic region and did not attempt to normalize the counts. Enrichment of Fru binding sites in genes that were significantly induced or repressed was tested using a Fisher's exact test [52]. Chromosomal enrichment for genes identified as differentially expressed was tested using a Fisher's exact test for each chromosomal arm.

Gene Ontology (GO) enrichment analysis was performed using Gene Ontology enrichment analysis and visualization tool (GOrilla) [29]. Target list containing FBgns from genes either induced or repressed in the $\mathrm{Fru}^{\mathrm{M}}$ over-expression or $\mathrm{Fru}^{\mathrm{M}}$ loss-of-function were supplied against a background list containing all 14903 FBgns to obtain significantly enriched ( $\mathrm{p}$ value $<10^{-3}$ ) GO terms for biological processes, cellular components, and molecular functions. Enriched protein domain analysis was implemented with the HolmBonferroni correction in the Flymine portal [28]. 


\section{Additional files}

Additional file 1: Table S1. Genes induced and repressed by Fru ${ }^{\mathrm{M}}$ isoforms in males (gene lists are based on the statistical tests and the $\geq 2$-fold difference criterion).

Additional file 2: Figure S1. Venn diagrams of comparisons.

Additional file 3: Table S2. Genes induced and repressed by Fru ${ }^{\mathrm{M}}$ isoforms in females. (gene lists are based on the statistical tests and the $\geq 2$-fold difference criterion).

Additional file 4: Table S3. Genomic locations for Fru ${ }^{\mathrm{M}}$ DNA binding motifs.

Additional file 5: Table S4. Gene Ontology analyses.

Additional file 6: Table S5. Genes induced and repressed by Fru ${ }^{\mathrm{M}}$, as determined by examination of fru P1 mutants and wild type males. All data described is included.

Additional file 7: Table S6. Statistical analysis of chromosomal distribution of genes regulated by $\mathrm{Fru}^{\mathrm{M}}$.

Additional file 8: Figure S2. Fru ${ }^{\mathrm{M}}$ is localized in the fru P1-expression pattern in flies over-expressing Fru ${ }^{\mathrm{MA}, \mathrm{B}}$ or ${ }^{\mathrm{C}}$.

Additional file 9: Figure S3. Courtship analyses.

Additional file 10: Figure S4. Schematic of how exon IDs are determined.

Additional file 11: Table S7. Exon region ID information and all associated data from this study.

Additional file 12: Table S8. Genes induced and repressed by Fru ${ }^{\mathrm{M}}$ isoforms in males (gene lists are based on the statistical tests).

Additional file 13: Table S9. Genes induced and repressed by Fru ${ }^{\mathrm{M}}$ isoforms in females (gene lists are based on the statistical tests).

\section{Abbreviations}

Dsx: Doublesex; fru: fruitless; GO: Gene Ontology; RNA-seq: RNA-sequencing; oligo: Oligonucleotide; DBD: DNA binding domain; CNS: Central nervous system.

\section{Competing interest}

The authors declare that they have no competing interests.

\section{Authors' contributions}

JED, MNA performed experiments. JED, JF, SK, LMM and MNA contributed to data and statistical analyses. JED, JF, SK, BB, LMM and MNA contributed to writing the manuscript. All authors read and approved the final manuscript.

\section{Acknowledgements}

This work was supported by research start-up funds from FSU and $\mathrm{NIH}$ grants R01GM073039 (PI is MNA), R01MH091561 (PI is S.V. Nuzhdin, MNA and LMM co-PIs). The contents of this article are solely the responsibility of the authors and do not necessarily represent the official views of the $\mathrm{NIH}$. We are grateful to S. Goodwin for UAS-Fru ${ }^{M}$ fly stocks, to Scott Greenberg for his experimental assistance, and D. Luo for comments on the manuscript. The data sets supporting the results of this article are available in the NCBI's Gene Expression Omnibus and are available through GEO series accession number GSE50515 (http://www.ncbi.nlm.nih.gov/geo/query/acc.cgi? acc $=$ GSE50515).

\section{Author details}

${ }^{1}$ Biomedical Sciences Department and Program in Neuroscience, Florida State University, College of Medicine, Tallahassee, FL 32303, USA. ${ }^{2}$ Genetics and Genomics Graduate Program, University of Florida, Gainesville, FL, USA. ${ }^{3}$ Genetics Institute, University of Florida, Gainesville, FL, USA. ${ }^{4}$ Department of Molecular Genetics and Microbiology, University of Florida, Gainesville, FL, USA. ${ }^{5}$ Cold Spring Harbor Laboratory, One Bungtown Road, Cold Spring Harbor, NY 11724, USA. ${ }^{6} J a n e l i a$ Farm Research Campus, HHMI, 19700 Helix Drive, Ashburn, VA 20147, USA. 7 Department of Biomedical Sciences, Florida State University, 1115 West Call Street, Tallahassee, FL 32306, USA.
Received: 20 June 2013 Accepted: 20 September 2013

Published: 27 September 2013

\section{References}

1. Yamamoto D: The neural and genetic substrates of sexual behavior in Drosophila. Adv Genet 2007, 59:39-66.

2. Villella A, Hall JC: Neurogenetics of courtship and mating in Drosophila. Adv Genet 2008, 62:67-184

3. Dauwalder B: The roles of fruitless and doublesex in the control of male courtship. Int Rev Neurobiol 2011, 99:87-105.

4. Manoli DS, Meissner GW, Baker BS: Blueprints for behavior: genetic specification of neural circuitry for innate behaviors. Trends Neurosci 2006, 29:444-451.

5. Gailey DA, Hall JC: Behavior and cytogenetics of fruitless in Drosophila melanogaster: different courtship defects caused by separate, closely linked lesions. Genetics 1989, 121:773-785.

6. Ryner LC, Goodwin SF, Castrillon DH, Anand A, Villella A, Baker BS, Hall JC, Taylor BJ, Wasserman SA: Control of male sexual behavior and sexual orientation in Drosophila by the fruitless gene. Cell 1996, 87:1079-1089.

7. Ito H, Fujitani K, Usui K, Shimizu-Nishikawa K, Tanaka S, Yamamoto D: Sexual orientation in Drosophila is altered by the satori mutation in the sex-determination gene fruitless that encodes a zinc finger protein with a BTB domain. Proc Natl Acad Sci USA 1996, 93:9687-9692.

8. Goodwin SF, Taylor BJ, Villella A, Foss M, Ryner LC, Baker BS, Hall JC: Aberrant splicing and altered spatial expression patterns in fruitless mutants of Drosophila melanogaster. Genetics 2000, 154:725-745.

9. Villella A, Gailey DA, Berwald B, Ohshima S, Barnes PT, Hall JC: Extended reproductive roles of the fruitless gene in Drosophila melanogaster revealed by behavioral analysis of new fru mutants. Genetics 1997 147:1107-1130.

10. Anand A, Villella A, Ryner LC, Carlo T, Goodwin SF, Song HJ, Gailey DA, Morales A, Hall JC, Baker BS, Taylor BJ: Molecular genetic dissection of the sex-specific and vital functions of the Drosophila melanogaster sex determination gene fruitless. Genetics 2001, 158:1569-1595.

11. Lee G, Foss M, Goodwin SF, Carlo T, Taylor BJ, Hall JC: Spatial, temporal, and sexually dimorphic expression patterns of the fruitless gene in the Drosophila central nervous system. J Neurobiol 2000, 43:404-426.

12. Demir E, Dickson BJ: Fruitless splicing specifies male courtship behavior in Drosophila. Cell 2005, 121:785-794.

13. Stockinger $P$, Kvitsiani $D$, Rotkopf $S$, Tirian L, Dickson BJ: Neural circuitry that governs Drosophila male courtship behavior. Cell 2005, 121:795-807.

14. Manoli DS, Foss M, Villella A, Taylor BJ, Hall JC, Baker BS: Male-specific fruitless specifies the neural substrates of Drosophila courtship behaviour. Nature 2005, 436:395-400

15. Kimura K, Ote M, Tazawa T, Yamamoto D: Fruitless specifies sexually dimorphic neural circuitry in the Drosophila brain. Nature 2005, 438:229-233.

16. Cachero S, Ostrovsky AD, Yu JY, Dickson BJ, Jefferis GS: Sexual dimorphism in the fly brain. Curr Biol 2010, 20:1589-1601.

17. Yu JY, Kanai MI, Demir E, Jefferis GS, Dickson BJ: Cellular organization of the neural circuit that drives Drosophila courtship behavior. Curr Biol 2010, 20:1602-1614.

18. Ruta V, Datta SR, Vasconcelos ML, Freeland J, Looger LL, Axel R: A dimorphic pheromone circuit in Drosophila from sensory input to descending output. Nature 2010, 468:686-690.

19. Usui-Aoki K, Ito H, Ui-Tei K, Takahashi K, Lukacsovich T, Awano W, Nakata H, Piao ZF, Nilsson EE, Tomida J, Yamamoto D: Formation of the male-specific muscle in female Drosophila by ectopic fruitless expression. Nat Cell Biol 2000, 2:500-506.

20. Ito H, Sato K, Koganezawa M, Ote M, Matsumoto K, Hama C, Yamamoto D: Fruitless recruits two antagonistic chromatin factors to establish single-neuron sexual dimorphism. Cell 2012, 149:1327-1338.

21. McQuilton P, St Pierre SE, Thurmond J: FlyBase 101-the basics of navigating FlyBase. Nucleic Acids Res 2012, 40:D706-D714.

22. Billeter JC, Villella A, Allendorfer JB, Dornan AJ, Richardson M, Gailey DA Goodwin SF: Isoform-specific control of male neuronal differentiation and behavior in Drosophila by the fruitless gene. Curr Biol 2006, 16:1063-1076

23. Klug SJ, Famulok M: All you wanted to know about SELEX. Mol Biol Rep 1994, 20:97-107. 
24. Ausubel FM: Current protocols in molecular biology. Brooklyn, N.Y. Media, Pa: Greene Pub. Associates; J. Wiley; 1987.

25. Graze RM, Novelo LL, Amin V, Fear JM, Casella G, Nuzhdin SV, McIntyre LM: Allelic imbalance in Drosophila hybrid heads: exons, isoforms, and evolution. Mol Biol Evol 2012, 29:1521-1532.

26. Sanders LE, Arbeitman MN: Doublesex establishes sexual dimorphism in the Drosophila central nervous system in an isoform-dependent manner by directing cell number. Dev Biol 2008, 320:378-390.

27. Rideout EJ, Dornan AJ, Neville MC, Eadie S, Goodwin SF: Control of sexual differentiation and behavior by the doublesex gene in Drosophila melanogaster. Nat Neurosci 2010, 13:458-466.

28. Lyne R, Smith R, Rutherford K, Wakeling M, Varley A, Guillier F, Janssens $H$, Ji W, McLaren P, North P, et al: FlyMine: an integrated database for Drosophila and Anopheles genomics. Genome Biol 2007, 8:R129.

29. Eden E, Navon R, Steinfeld I, Lipson D, Yakhini Z: GOrilla: a tool for discovery and visualization of enriched GO terms in ranked gene lists. BMC Bioinform 2009, 10:48.

30. Al-Anzi B, Sapin V, Waters C, Zinn K, Wyman RJ, Benzer S: Obesity-Blocking Neurons in Drosophila. Neuron 2009, 63:329-341.

31. Goldman TD, Arbeitman MN: Genomic and functional studies of Drosophila sex hierarchy regulated gene expression in adult head and nervous system tissues. PLoS Genet 2007, 3:e216.

32. Lazareva AA, Roman G, Mattox W, Hardin PE, Dauwalder B: A role for the adult fat body in Drosophila male courtship behavior. PLoS Genet 2007, 3:e16.

33. Dalton JE, Lebo MS, Sanders LE, Sun F, Arbeitman MN: Ecdysone receptor acts in fruitless- expressing neurons to mediate drosophila courtship behaviors. Curr Biol 2009, 19:1447-1452.

34. Robinson SW, Herzyk P, Dow JA, Leader DP: FlyAtlas: database of gene expression in the tissues of Drosophila melanogaster. Nucleic Acids Res 2013, 41:D744-D750.

35. Benton R, Vannice KS, Gomez-Diaz C, Vosshall LB: Variant lonotropic Glutamate Receptors as Chemosensory Receptors in Drosophila. Cell 2009, 136:149-162.

36. Kimura K, Hachiya T, Koganezawa M, Tazawa T, Yamamoto D: Fruitless and doublesex coordinate to generate male-specific neurons that can initiate courtship. Neuron 2008, 59:759-769.

37. Rideout EJ, Billeter JC, Goodwin SF: The sex-determination genes fruitless and doublesex specify a neural substrate required for courtship song. Curr Biol 2007, 17:1473-1478.

38. Taylor BJ, Villella A, Ryner LC, Baker BS, Hall JC: Behavioral and Neurobiological Implications of Sex-Determining Factors in Drosophila. Dev Genet 1994, 15:275-296.

39. Chang PL, Dunham JP, Nuzhdin SV, Arbeitman MN: Somatic sex-specific transcriptome differences in Drosophila revealed by whole transcriptome sequencing. BMC Genom 2011, 12:364.

40. Catalan A, Hutter S, Parsch J: Population and sex differences in Drosophila melanogaster brain gene expression. BMC Genom 2012, 13:654.

41. Conrad T, Akhtar A: Dosage compensation in Drosophila melanogaster: epigenetic fine-tuning of chromosome-wide transcription. Nat Rev Genet 2011, 13:123-134.

42. Lemos B, Branco AT, Hartl DL: Epigenetic effects of polymorphic $Y$ chromosomes modulate chromatin components, immune response, and sexual conflict. Proc Natl Acad Sci USA 2010, 107:15826-15831.

43. Sexton T, Yaffe E, Kenigsberg E, Bantignies F, Leblanc B, Hoichman M, Parrinello H, Tanay A, Cavalli G: Three-dimensional folding and functional organization principles of the Drosophila genome. Cell 2012, 148:458-472.

44. Song HJ, Billeter JC, Reynaud E, Carlo T, Spana EP, Perrimon N, Goodwin SF, Baker BS, Taylor BJ: The fruitless gene is required for the proper formation of axonal tracts in the embryonic central nervous system of Drosophila. Genetics 2002, 162:1703-1724.

45. Newberg LA, Thompson WA, Conlan S, Smith TM, Mccue LA, Lawrence CE: A phylogenetic Gibbs sampler that yields centroid solutions for cisregulatory site prediction. Bioinformatics 2007, 23:1718-1727.

46. Arbeitman MN, Hogness DS: Molecular chaperones activate the Drosophila ecdysone receptor, an RXR heterodimer. Cell 2000, 101:67-77.

47. Langmead B, Trapnell C, Pop M, Salzberg SL: Ultrafast and memory-efficient alignment of short DNA sequences to the human genome. Genome Biol 2009, 10:R25

48. Trapnell C, Pachter L, Salzberg SL: TopHat: discovering splice junctions with RNA-Seq. Bioinformatics 2009, 25:1105-1111.
49. Frith $M C$, Wan $R$, Horton $P$ : Incorporating sequence quality data into alignment improves DNA read mapping. Nucleic Acids Res 2010, 38:e100.

50. Mortazavi A, Williams BA, McCue K, Schaeffer L, Wold B: Mapping and quantifying mammalian transcriptomes by RNA-Seq. Nat Meth 2008 5:621-628.

51. Benjamini $Y$, Hochberg $Y$ : Controlling the False Discovery Rate - a Practical and Powerful Approach to Multiple Testing. J R Stat Soc B Methodol 1995, 57:289-300.

52. Beissbarth T, Speed TP: GOstat: find statistically overrepresented Gene Ontologies within a group of genes. Bioinformatics 2004, 20:1464-1465

53. Bailey TL, Gribskov M: Methods and statistics for combining motif match scores. J Comput Biol 1998, 5:211-221.

doi:10.1186/1471-2164-14-659

Cite this article as: Dalton et al:: Male-specific Fruitless isoforms have different regulatory roles conferred by distinct zinc finger DNA binding domains. BMC Genomics 2013 14:659.

\section{Submit your next manuscript to BioMed Central and take full advantage of:}

- Convenient online submission

- Thorough peer review

- No space constraints or color figure charges

- Immediate publication on acceptance

- Inclusion in PubMed, CAS, Scopus and Google Scholar

- Research which is freely available for redistribution 